\title{
Labor Taxes and Decision about FDI in the EU
}

\author{
Jan Tecl ${ }^{*}$
}

\begin{abstract}
:
This paper analyzes the relationship between tax variables and foreign direct investments. There are many studies with analysis of influence of corporate income tax, but only few with focus on individual taxation and social security contributions. The analysis is done for the decision if do FDI or do not do and about decision about amount of FDI. On the decision about realization of FDI has impact GDP per capita of home and partner country and distance between countries. GDP per capita of home country increase probability of location of FDI, GDP per capita and distance decrease the probability of the location of FDI in the partner country. Based on the results, on the amount of FDI have positive impact GDP variables and other variables - e.g. differences in corporate tax rate. Negative impact has distance between countries. The impact of social security payment is not obvious, because it differs based on the fact of average wage of employee (for higher than average earnings the relationship is negative, for average earnings the relationship is positive).
\end{abstract}

Key words: FDI; Taxation; Individual taxation.

JEL classification: $\mathrm{F} 21, \mathrm{H} 24$.

\section{Introduction and Literature Review}

Foreign direct investment (FDI) is one of the best measurements how the country is successful with attracting foreign investors and how the competitiveness could be measured. There are many possible factors which could influence the decision about location and amount of the FDI. Demirhan and Masca (2008) and Becker et al., (2005) described some of these factors - market size measured by GDP, openness, labour cost and productivity, political risk, infrastructure, growth and tax.

The aim of this paper will be to analyze influence of tax factors on the FDI. The tax factors will cover especially labour taxation (not only personal income tax, but also the social security contributions paid by employer and employee).

The analysis of influence of tax variables could be done in two steps based on the 2 step estimation model described in Hansson and Olofsdotter (2014). The first step is to analyze if the FDI should be located in given country and the second step analyze the amount of FDI.

Jan Tecl; University of Economics, Prague, Faculty of Finance and Accounting, Department of Public Finance, W. Churchill Sq. 4, 13067 Prague, Czech Republic, <xtecj02@vse.cz>.

The contribution is processed as an output of a research project Public finance in the Czech Republic and the EU under the registration number F1/1/2016. 
There are many papers and studies, which analyze the influence of corporate income tax on FDI as this could be the most important tax factor for potential investors (Wolff (2007); Bieltvedt Skeie (2017); Bénassy-Quéré et al. (2005); Mooij and Ederveen (2006); Janíčková and Baranová, (2013). The result shows negative impact of corporate taxation on the FDI

Other authors analyze the influence of other taxes (not only the corporate income tax). Buettner and Wamser (2009) analyze other tax variables like sales tax, VAT, excise and import duties, property tax and labour tax (taxes on skilled labour). Also Popovici (2016) analyze the impact of corporate income tax, labour tax and value added tax on the FDI. Based on these studies, VAT and sales tax has not statistically significant influence on the FDI, import duties has statistically significant negative influence on FDI and labour tax has statistically significant negative influence on the FDI.

The implication of labour taxation on FDI was analyzed by Hansson and Olofsdotter (2014) and Egger and Radulescu (2011). The results show that labour taxes differences between countries imply negatively the FDI with the elasticity of -2. Higher negative influence has personal income tax paid by employee than the tax paid by employer. The reason may be the fact that tax paid by employee directly decrease received net payment, the employer payment is not visible for the employee.

Previously, labour was considered as static production factor. Now this opinion changes especially by the group of highly paid individuals (e.g. managers), because higher taxes on personal income could decrease effort of the highly paid individuals and this will decrease profit of the company in given country (Egger and Radulescu, 2011).

These authors distinguish between nominal tax rate (e.g. (Demirhan and Masca, 2008) and effective tax rate (Mooij and Ederveen, 2006). Hansson and Olofsdotter (2014) discuss that for the first step are more important the effective average tax rates and for second step is more important the effective marginal tax rate.

Based on the literature review, following factors were considered as important by decision about FDI - GDP, GDP per capita, distance, difference in labour costs, difference of marginal corporate tax, difference in implicit and effective labour taxes.

Based on the author's interest, the variables related to the social security payments were added and explanatory variables. These results could be used also in my dissertation thesis. The value for people with higher wage is more decisive about the FDI. 


\section{Data and Methodology}

There are many factors, which have influence on amount of FDI, which are located in given country. In this paper will be measured the relationship between FDI and other variables (especially tax variables). Tax variables are chosen because there are not many papers, which analyzed this field and secondly the results could be used in my dissertation thesis.

The methodology used in this paper will be use similar to methodology of Hansson and Olofsdotter, 2014 who follows selection model. However, for the first step a logit model will be used instead of linear regression as logit model fits more based on the possible results. This methodology allows us to measure the relationship in aggregate amounts for each country.

Decision about FDI is done in 2 steps. First investor decides, if the investment will be done in given country and if yes, then he decides about the amount of investment. The same approach will be used in this paper.

The first step uses dummy variable 1 , if FDI is positive and 0 otherwise. This analysis could give us information about factor, which are important for decision making about location of FDI.

The second step analyses the variables, which influence amount of FDI, if the FDI is done (e.g. in first step is variable equal to 1 ).

Analysis of first step will be done as logit model, as the output is binary ( 0 or 1$)$ and this model is used in cases of choices and decision cases. This is our case as the investors first decide about the placement.

The logit model formula is following:

$$
y=\ln \left(\frac{p}{1-p}\right)
$$

Where y is influences of all factors, which could be decisive for FDI placement and $\mathrm{p}$ means probability that the placement will be done in given country.

The equation (1) could be rewrite as following for measuring probability:

$$
p=\frac{e^{y}}{1+e^{y}}
$$

Results of the logit model could not be easily interpreted, because the dependence is not linear, but it is exponential. Influence of increase of explanatory variable by 1 on the dependent variable is not the same for the whole scale (e.g. in the middle the dependent variable could increase by $1 \%$, in the higher part it could be increase only about $0,05 \%$ ). 
The first step based on the methodology used is to analyze if there is any flow of FDI in this direction. For this purposes the following equation (3) is used:

$$
s_{i j t}=\beta_{0}+X_{1 i j t} \beta_{2}+\varepsilon_{1 i j t}
$$

Where $s_{i j t}$ is variable which implies, if there was positive flow of $F D I\left(s_{i j t}=1\right)$ and otherwise $\left(\mathrm{s}_{\mathrm{ijt}}=0\right), \beta_{0}$ is constant, $Y$ means values of explanatory variables for investment country $i$ and hosting country $j$ in year $t$ and $\varepsilon_{2 i j t}$ means error term.

Analysis for the second step will be done as regression analysis for period from 2005 to 2012 for 28 EU countries, which are also part of OECD. Generally, this gives us 6272 observations. For each year were found variables for one direction between couple of two countries (GDP and tax variables and also amount of FDI and this values were analyzed. Because of missing data for some observations and countries, we have only 3000 observations. FDI is positive only in 2015 cases. For computing this analysis, software Gretl was used.

Hypothesis is that labour taxation has negative influence on FDI. Partially, the influence of social security and taxation as such will be analyzed.

Amount of FDI is influenced by many variables with different power and direction (negative or positive) plus the error term should be considered for each year $(t)$ and investing country $(i)$ and host country $(j)$. This analysis is done only in case, that the amount of FDI in this direction is positive.

$$
F D I_{i j t}=\beta_{0}+X_{1 i j t} \beta_{1}+\varepsilon_{1 i j t}
$$

Where $F D I_{i j t}$ is total value of the FDI of the investment country $i$ and hosting country $j$ in the year $t, \beta_{0}$ is constant, $X_{l i j t}$ means values of all explanatory variables for investment country $i$ and hosting country $j$ in year $t, \beta$ is regression coefficient of $F D I$ on changes of explanatory values and $\varepsilon_{l i j t}$ means error term. Variables from which are composed variables $X 1_{i j t}$ and $X 2_{i j t}$ may not be the same.

The second equation could be written in log-semi log specification. In the equation, some variables have high variability and because of their high variability the values of these variables are used as natural logarithm - amount of FDI flow between countries, absolute values related to GDP (GDP, GDP per capita) and distance. The other variables which are computed as differences between home and partner country, will be not computed as logarithm (the variability is low). For more information about variables, please see table (1) The equation (2) could be written as follows:

$$
\begin{gathered}
\ln F D I_{i j t}=\alpha_{1} \ln G D P D o m+\alpha_{2} \ln \text { GDPPar }+\alpha_{3} \ln \text { GDPpCapDom }+ \\
\alpha_{4} \ln G D P p C a p P a r+\alpha_{5} \ln \text { Dis }+\gamma_{6} V_{1}+\ldots+\gamma_{n} V_{n}+\varepsilon_{1 i j t}
\end{gathered}
$$


Where $\ln F D I_{i j t}$ is natural logarithm of $F D I$ flow of the investment from country $i$ into hosting country $j$ in the year $t, V_{n}$ means values of each explanatory variable for investment country $i$ and hosting country $j$ in year $t$ (other than used in previous part of equation), $\alpha$ is regression coefficient, $\gamma$ means dependence between amount of $F D I$ on changes of explanatory values and $\varepsilon_{1 j t}$ means error term (for description of all variables, please see table (1)).

The dependent variable will be amount of FDI (natural logarithm) and information if there was positive FDI or not. Source of these data is Eurostat. The FDI will be measured as inflow of $F D I$ to one country from each country from EU (dataset bop_fdi_flow_r2). In table (1) are stated all variables together with their sources.

\section{Tab. 1 Variables, their source and description}

\begin{tabular}{|c|c|c|}
\hline Variable & Description & Source \\
\hline $\operatorname{lnFDI}$ & amount of FDI flow & Eurostat \\
\hline $\operatorname{lnDist}$ & distance between capital cities & CEPII \\
\hline lnGDPdom & Gross domestic product (GDP) of given country & OECD \\
\hline lnGDPpar & Gross domestic product (GDP) of partner country & OECD \\
\hline $\operatorname{lnGDPpCapDom}$ & GDP per capita & OECD \\
\hline lnGDPpCapPar & GDP per capita & OECD \\
\hline DifLabCos & labor cost difference & OECD \\
\hline DifCorMar & top marginal corporation tax difference & OECD \\
\hline DifLabRat100 & $\begin{array}{l}\text { labour tax rate for individual with } 100 \% \text { of AW } \\
\text { difference }\end{array}$ & $\begin{array}{l}\text { OECD Taxing } \\
\text { wages }\end{array}$ \\
\hline DifLabRat167 & $\begin{array}{l}\text { labour tax rate for individual with } 167 \% \text { of AW } \\
\text { difference }\end{array}$ & $\begin{array}{l}\text { OECD Taxing } \\
\text { wages }\end{array}$ \\
\hline DifTaxWed100 & tax wedge for individual with $100 \%$ of AW difference & $\begin{array}{l}\text { OECD Taxing } \\
\text { wages }\end{array}$ \\
\hline DifTaxWed167 & tax wedge for individual with $167 \%$ of AW difference & $\begin{array}{l}\text { OECD Taxing } \\
\text { wages }\end{array}$ \\
\hline DifWedMar100 & $\begin{array}{l}\text { marginal tax wedge for individual with } 100 \% \text { of AW } \\
\text { difference }\end{array}$ & $\begin{array}{l}\text { OECD Taxing } \\
\text { wages }\end{array}$ \\
\hline DifWedMar167 & $\begin{array}{l}\text { marginal tax wedge for individual with } 167 \% \text { of AW } \\
\text { difference }\end{array}$ & $\begin{array}{l}\text { OECD Taxing } \\
\text { wages }\end{array}$ \\
\hline DifIndTop & top marginal individual tax rate difference & OECD \\
\hline DifIndTopSS & $\begin{array}{l}\text { top marginal individual tax rate plus social contribution } \\
\text { difference }\end{array}$ & OECD \\
\hline DifImpTax & implicit tax rate on labor difference $r$ & Eurostat \\
\hline DifSSEE100 & $\begin{array}{l}\text { social security paid by employee with } 100 \% \text { of AW } \\
\text { difference }\end{array}$ & $\begin{array}{l}\text { OECD Taxing } \\
\text { wages }\end{array}$ \\
\hline
\end{tabular}


Tecl, J.: Labor Taxes and Decision about FDI in the EU.

\begin{tabular}{lll}
\hline Variable & Description & Source \\
\hline DifSSEE167 & $\begin{array}{l}\text { social security paid by employee with 167\% of AW } \\
\text { difference }\end{array}$ & OECD Taxing \\
& $\begin{array}{l}\text { wages } \\
\text { Docial security paid by employer with 100\% of AW } \\
\text { difference }\end{array}$ & $\begin{array}{l}\text { OECD Taxing } \\
\text { wages }\end{array}$ \\
DifSSER167 & $\begin{array}{l}\text { social security paid by employer with 167\% of AW } \\
\text { difference }\end{array}$ & $\begin{array}{l}\text { OECD Taxing } \\
\text { wages }\end{array}$ \\
\hline
\end{tabular}

Source: Author's computation.

Note: $\mathrm{AW}=$ average wage.

The measurements are used for single individuals without children with $100 \%$ and $167 \%$ of average salary in the economy. As the salary of individuals, who manage the company in given country (and whose effort is influenced by the net salary), is higher than average wage, these variables should be computed also for $400 \%$ and $600 \%$ of average wage. As these data are not available, the analysis was done with $100 \%$ and $167 \%$ of average salary.

Variables related to the GDP and distances were calculated for purpose of analysis as natural logarithm of the values, the others were calculated as difference between home and partner country values.

\section{Results and Discussion}

Based on the literature, the variables relates to GDP (home and partner), GDP per capita (home and partner), distance between countries, labour costs difference and difference in marginal corporation tax were found as important and because of this, they were used in all models.

Table 2 shows results for 2 steps decision making model. The first step was to measure if the FDI will flow into the country and the second step is analysis of the amount of FDI. The analysis was divided in these 2 steps and also there were introduced 2 models which may differ in variables.

In the first model were used all variables to measure their total impact. In second model were used only variables related to the GDP, distance, labour cost, marginal corporation tax and tax wedge and implicit tax and variables related to the influence of social security (paid by employer and employee) on the decision making about location and amount of FDI. As written above, the measurement of influence of social security payments on the location and amount of FDI is goal of this paper. In the third and fourth model was deeply analyzed the influence of wage taxation (also marginal rates) for employee with $100 \%$ and $167 \%$ of average wage.

One could assume that GDP and GDP per capita should have positive impact on the location and amount of FDI. Based on the literature review, GDP of the partner country has negative impact on location of FDI. The influence of distance on the 
location of FDI is not clear. Difference in taxes (computed as value for home country minus value for partner country) should have positive impact as the partner country has lower tax burden and the investment as not taxed so much. Higher impact should have taxation of employee with higher wage than average, than employee with average wage. The same results could be expected also by the social security contribution. However, the impact is not clear.

Based on the results of the logit model, it is possible to say, which variables are statistically significant and which are not. We can also compare value of coefficient and value of standard deviation. A higher value of this ratio means higher accuracy of the number.

Tab. 2 Results for models 1 and model 2

\begin{tabular}{|c|c|c|c|c|c|c|c|c|c|c|}
\hline \multirow[b]{2}{*}{ Variable } & \multicolumn{5}{|c|}{ Model 1} & \multicolumn{5}{|c|}{ Model 2} \\
\hline & $\begin{array}{l}\text { placeme } \\
\text { coef. }\end{array}$ & & $\mathbf{z}$ & $\begin{array}{l}\text { amount } \\
\text { coef. }\end{array}$ & & $\begin{array}{l}\text { placeme } \\
\text { coef. }\end{array}$ & & $\mathbf{z}$ & $\begin{array}{l}\text { amount } \\
\text { coef. }\end{array}$ & \\
\hline const & 6,1894 & $* * *$ & 3,30 & $-48,8814$ & $* * *$ & 6,3313 & $* * *$ & 3,39 & $-48,8628$ & $* * *$ \\
\hline $\operatorname{lnDist}$ & $-0,3193$ & $* * *$ & $-5,32$ & $-0,9291$ & $* * *$ & $-0,3214$ & $* * *$ & $-5,36$ & $-0,9274$ & $* * *$ \\
\hline lnGDPhome & $-0,0045$ & & $-0,09$ & 0,6942 & $* * *$ & 0,0295 & & 0,73 & 0,6819 & $* * *$ \\
\hline lnGDPpar & 0,0633 & & 1,31 & 0,6134 & $* * *$ & 0,0288 & & 0,74 & 0,6273 & $* * *$ \\
\hline lnGDPpCapH & 0,8729 & $* *$ & 2,41 & 2,9569 & $* * *$ & 0,3576 & & 1,28 & 2,6775 & $* * *$ \\
\hline lnGDPpCapP & $-1,2184$ & $* * *$ & $-3,39$ & 2,0893 & $* * *$ & $-0,7155$ & $* * *$ & $-2,59$ & 2,3651 & $* * *$ \\
\hline DifLabCos & 0,0000 & $* * *$ & $-2,77$ & 0,0000 & & 0,0000 & $* *$ & $-2,23$ & 0,0000 & $* *$ \\
\hline DifCorMar & $-0,0158$ & & $-1,25$ & 0,0012 & & $-0,0076$ & & $-1,11$ & 0,0099 & \\
\hline DifIndTop & 0,0138 & & 1,51 & $-0,0063$ & & 0,0125 & & 1,51 & $-0,0046$ & \\
\hline DifImpTax & $-0,0043$ & & $-0,38$ & $-0,0217$ & $* *$ & 0,0100 & & 1,48 & $-0,0086$ & \\
\hline DifLabRate167 & 0,0680 & & 0,36 & $-0,1840$ & & & & & & \\
\hline DifTaxWed167 & $-0,0360$ & & $-0,17$ & 0,2574 & & & & & & \\
\hline DifWedMar167 & $-0,0088$ & & $-0,85$ & $-0,0088$ & & & & & & \\
\hline DifLabRat100 & $-0,0478$ & & $-0,29$ & 0,1616 & & & & & & \\
\hline DifTaxWed100 & 0,0746 & & 0,37 & $-0,1907$ & & & & & & \\
\hline DifWedMar100 & $-0,0375$ & $* * *$ & $-3,81$ & $-0,0098$ & & & & & & \\
\hline DifIndTopSS & $-0,0052$ & & $-0,52$ & 0,0090 & & $-0,0092$ & & $-1,18$ & 0,0075 & \\
\hline DifSSEE167 & 0,0188 & & 0,09 & $-0,4017$ & $* *$ & $-0,0548$ & $*$ & $-1,94$ & $-0,1823$ & $* * *$ \\
\hline DifSSER167 & 0,0141 & & 0,15 & 0,0119 & & 0,0056 & & 0,16 & 0,0614 & $*$ \\
\hline
\end{tabular}


Tecl, J.: Labor Taxes and Decision about FDI in the EU.

\begin{tabular}{|c|c|c|c|c|c|c|c|c|}
\hline \multirow[b]{2}{*}{ Variable } & \multicolumn{4}{|c|}{ Model 1} & \multicolumn{4}{|c|}{ Model 2} \\
\hline & $\begin{array}{l}\text { placement } \\
\text { coef. }\end{array}$ & $\mathbf{z}$ & $\begin{array}{l}\text { amount } \\
\text { coef. }\end{array}$ & & $\begin{array}{l}\text { placement } \\
\text { coef. }\end{array}$ & $\mathbf{z}$ & $\begin{array}{l}\text { amount } \\
\text { coef. }\end{array}$ & \\
\hline DifSSEE100 & $-0,0027$ & $-0,01$ & 0,3557 & $* *$ & $0,0482 *$ & 1,89 & 0,1602 & $* * *$ \\
\hline DifSSER100 & $-0,0068$ & $-0,07$ & $-0,0160$ & & $-0,0038$ & $-0,11$ & $-0,0577$ & $*$ \\
\hline $\begin{array}{l}\% \text { of predicted } \\
\text { cases }\end{array}$ & 67,6 & & & & 67,4 & & & \\
\hline $\begin{array}{l}\text { coef, } \\
\text { determination } \\
(\%)\end{array}$ & & & 58,33 & & & & 58,09 & \\
\hline
\end{tabular}

Source: OECD, Eurostat, CEPII, own calculation.

Note: Coef $=$ coefficient, $\mathrm{z}=$ ratio between coefficient and standard deviation, $\mathrm{SS}=$ statistical significant level, $* * *=1 \%, * *=5 \%, *=10 \%$.

Tab. 3 Results for model 3 and model 4 (continue of table 2)

\begin{tabular}{|c|c|c|c|c|c|c|c|c|c|c|}
\hline \multirow[b]{2}{*}{ Variable } & \multicolumn{5}{|c|}{ Model 3} & \multicolumn{5}{|c|}{ Model 4} \\
\hline & $\begin{array}{l}\text { Placem } \\
\text { coef. }\end{array}$ & & $\mathbf{z}$ & $\begin{array}{l}\text { Amount } \\
\text { coef. }\end{array}$ & & $\begin{array}{l}\text { Placeme } \\
\text { coef. }\end{array}$ & & $\mathbf{z}$ & $\begin{array}{l}\text { Amount } \\
\text { coef. }\end{array}$ & \\
\hline const & 6,2359 & $* * *$ & 3,35 & $-\overline{48,7946}$ & $* * *$ & 6,0322 & $* * *$ & 3,24 & $-48,9227$ & $* * *$ \\
\hline lnDist & $-0,3209$ & $* * *$ & $-5,36$ & $-0,9238$ & $* * *$ & $-0,3168$ & $* * *$ & $-5,29$ & $-0,9220$ & $* * *$ \\
\hline lnGDPhome & 0,0642 & & 1,60 & 0,7681 & $* * *$ & 0,0428 & & 1,06 & 0,7523 & $* * *$ \\
\hline lnGDPpar & $-0,0021$ & & $-0,05$ & 0,5436 & $* * *$ & 0,0210 & & 0,53 & 0,5598 & $* * *$ \\
\hline lnGDPpCapH & 0,6164 & $* *$ & 2,32 & 3,1146 & $* * *$ & 1,0554 & $* * *$ & 3,50 & 3,4757 & $* * *$ \\
\hline lnGDPpCapP & $-0,9679$ & $* * *$ & $-3,67$ & 1,9185 & $* * *$ & $-1,3906$ & $* * *$ & $-4,64$ & 1,5680 & $* * *$ \\
\hline DifLabCos & 0,0000 & $* * *$ & $-3,54$ & 0,0000 & & 0,0000 & $* * *$ & $-3,72$ & 0,0000 & \\
\hline DifCorMar & $-0,0078$ & & $-1,06$ & 0,0031 & & $-0,0237$ & $* * *$ & $-2,69$ & $-0,0115$ & \\
\hline DifIndTop & 0,0070 & & 1,52 & 0,0003 & & 0,0134 & $* * *$ & 3,24 & 0,0083 & $* *$ \\
\hline DifImpTax & 0,0138 & & 1,55 & $-0,0141$ & $*$ & $-0,0036$ & & $-0,35$ & $-0,0300$ & $* * *$ \\
\hline DifLabRate167 & 0,0093 & & 1,40 & 0,0208 & $* * *$ & & & & & \\
\hline DifTaxWed167 & $-0,0056$ & & $-0,59$ & $-0,0002$ & & & & & & \\
\hline DifWedMar167 & $-0,0072$ & & $-1,58$ & $-0,0063$ & & & & & & \\
\hline DifLabRat100 & & & & & & $-0,0011$ & & $-0,17$ & 0,0071 & \\
\hline DifTaxWed100 & & & & & & 0,0537 & $* * *$ & 3,45 & 0,0417 & $* * *$ \\
\hline
\end{tabular}


European Financial and Accounting Journal, 2017, vol.12, no. 2, pp. 41-54.

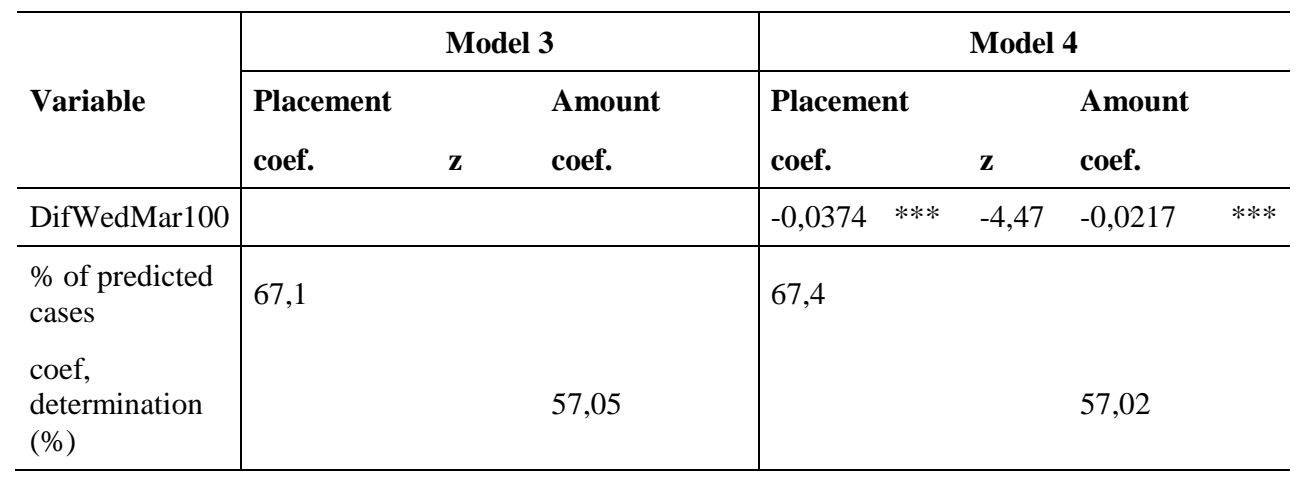

Source: OECD, Eurostat, CEPII, own calculation.

Note: Coef $=$ coefficient, $\mathrm{z}=$ ratio between coefficient and standard deviation, $\mathrm{SS}=$ statistical significant level, $* * *=1 \%, * *=5 \%, *=10 \%$.

The results for FDI location decision making are mainly not surprising, because the GDP of home country increase probability of the location of investment and it is important for ability of domestic companies and individuals to make investments abroad. GDP of the partner country shows, that the investment will be in partner country able to earn requested profit, because there is other economic activity, by which inhabitants could earn money for acquisition of goods or services provided by the investment. However, in model 1 is value for GDP of home country (the same is in third model for GDP of partner country) below zero, but the value of $\mathrm{z}$ is around zero, so it means, that standard deviation is high and we do not comment this value because it should not to be part of the model. These values are also statistically not significant.

The same conclusion is also valid for indicators GDP per capita of home country, because the GDP should be calculated on each inhabitant to measure performance of the economy. This variable is statistically significant (with the exception of model 2).

On the other hand, it is surprising, that GDP per capita of partner country has negative influence on probability of location of investment in the partner country in all 4 models. This variable is statistically significant in all 4 models.

Another statistically important variable is distance. Neighbourhoods' countries may have similar demand, needs or tastes and it is also easier to manage FDI on short distance (most often at the beginning, until local leadership is set up). Also the borders are no limit for business and for companies located near borders, it could be economical to locate another production place to the other state.

Difference in labour costs negatively influences the location of FDI. However, this influence is low. 
Based on the results, difference in marginal tax rates of corporations decrease the probability of FDI placement. The result is statistically significant only in the fourth model. The influence is really small, but still, the expected influence should be opposite.

On the other hand, difference in top individual income tax rate increases the probability that the FDI will be done in the partner country. This is in line with literature review, where is discussed the motivation of highly paid employees.

Results for influence of social security payments (paid by employee and employer) are not clear and it should be analyzed deeply in another paper. Social security paid by employee could be considered as kind of tax and based on the results of the model 2, the result for employee with salary above average is in line with expectation (the relationship is possitive).

Models predict more than $67 \%$ of cases correctly. However, models have problem with cases, where the reality is equal zero (no positive FDI flow) but the models predict positive flow of FDI.

Models, which analyzed the amount of FDI flowing from home country to the partner country could be analyzed and statistically tested. The same statistically significant variables are distance, GDP of both countries and GDP per capita of the home and partner country. Only the distance has negative relationship with the amount of FDI, other abovementioned variables has positive relationship.

The reason positive statistical significance may be the fact that higher GDP has a home economy, a higher ability to do foreign investment. Based on the theory, the savings (and related investments) are positively dependent on the product (GDP). This argumentation could be also used for variable of GDP per capita. All these results are in line with expectation and literature review.

Another statistical significant variable is implicit tax on labour. This mean, that amount of FDI depend on all taxes and compulsory payments related to the employment. The relationship is negative and that means that if the partner country decrease implicit tax on labour (e.g. decrease tax, social security payments), the amount of FDI increases.

Interesting result give us models for the variable of social security payment done by employee for employee with $100 \%$ of average wage and $167 \%$ of average wage. One could assume that the direction of influence on the FDI should be the same, but it differs. The reason for positive relationship between differences in social security payments by employee with $100 \%$ of average wage could be the fact that for some of the FDI are important workers which receive average wage and for investor is important to consider also related social payments. The same situation (but with opposite relationship) is also for the social security contributions paid by employer, but these results are not statistically significant. 


\section{Conclusions}

There are many studies which analyze the influence of corporate income tax on FDI, but just only few about the influence of individual taxation on FDI. The aim of this paper was to analyze on latest data (period from 2005 to 2012) the influence of especially tax variables on the FDI. This analysis was done for 2 moments - first for the decision if the FDI will be done or not and secondly the analysis of amount of FDI.

This relationship was more analyzed from the point of social security contributions and other variables related to the individual taxation. As the taxation decrease net income of employees (if the gross wage is fixed) and based on the assumption, that the effort of employees related to the net income, all these variables should have negative impact on the FDI.

There were introduced 4 models, the first one covered all variables, the second one covered GDP variables and social security contributions divided into employee and employer part and the third and fourth one covered GDP and individual statutory taxes and tax wedges for employees with $100 \%$ and $167 \%$ of average wage.

Based on the results, there were found expected influence between GDP variables and fact, if FDI will be located in given country or not. All these variables have positive impact on the location. Higher value of GDP per capita of home country, increase the possibility of location of investment in given country. However, GDP per capita of partner country is exemption and this value decrease probability of FDI placement in given country.

The amount of FDI is positively influenced by GDP of home and partner countries, GPD per capita of home and partner country and negatively it is influenced by the distance between biggest agglomerations. These statistically significant variables are the same for all models. These results are according to expectation.

The influence of difference in social security payment of employee and employer for employee with $100 \%$ and $167 \%$ of average wage differs. Statistically significant are in 2 models, differences in social security payments paid by employee. One could assume, that the difference should have positive impact on the amount of FDI (in partner country is lower taxation than in home country. But based on the results, social security payment of employee with $167 \%$ of average wage has negative impact on FDI. The difference in social security for worker with average wage positively influences the amount of FDI.

Following research could be done in the field of taxation on individuals with higher income (e.g. $400 \%$ or $600 \%$ of average wage). Also the situation of the 
Tecl, J.: Labor Taxes and Decision about FDI in the EU.

influence of social security payment by employees with different amount of average wage should be analyzed.

\section{References}

Becker, S. O., Ekholm, K., Jäckle, R., Muendler, M. A., 2005. Location Choice and Employment Decisions. A Comparison of German and Swedish Multinationals. Rev. World Econ. 141, 693-731. DOI: 10.1007/s10290-005-00526.

Bénassy-Quéré, A., Fontagné, L., Lahrèche-Révil, A., 2005. How Does FDI React to Corporate Taxation? Int. Tax Public Finance 5, 583-603. DOI: 10.1007/s10797005-2652-4.

Bieltvedt S. Ø., 2017. International differences in corporate taxation, foreign direct investment and tax revenue (OECD Economics Department Working Papers No. 1359). DOI: $10.1787 /$ ddd 8669 b-en.

Buettner, T., Wamser, G., 2009. The impact of nonprofit taxes on foreign direct investment: evidence from German multinationals. Int. Tax Public Finance 3, 298320. DOI: 10.1007/s10797-008-9063-2.

Centre d'Etudes Prospectives et d'Informations Internationales. Available from: <http://www.cepii.fr/>. [12 March 2017].

Demirhan, E., Masca, M., 2008. Determinants of foreign direct investment flows to developing countries: a cross-sectional analysis. Prague Econ. Pap. 4, 356-369. DOI: $10.18267 /$ j.pep.337.

Egger, P., Maria Radulescu, D., 2011. Labor Taxation and Foreign Direct Investment*: Labor taxation and foreign direct investment. Scand. J. Econ. no-no. DOI: 10.1111/j.1467-9442.2011.01653.x.

Eurostat. Available from: <http://ec.europa.eu/eurostat>. [20 February 2017].

Hansson, A., Olofsdotter, K., 2014. Labor Taxation and FDI Decisions in the European Union. Open Econ. Rev. 2, 263-287. DOI: 10.1007/s11079-013-9282-8. Janíčková, L., Baranová, V., 2013. Vliv efektivních daňových sazeb a jejich komponent na přímé zahraniční investice - případ členských zemí EU. Polit. Ekon. 2, 209-228. DOI: 10.18267/j.polek.895.

Mooij, R. A. de, Ederveen, S., 2006. What a difference does it make? Understanding the empirical literature on taxation and international capital flows, European economy Economic papers. Europ. Comm., Directorate-General for Economic and Financial Affairs, Brussels.

Organisation for Economic Co-operation and Development. Available from: <http://www.oecd-ilibrary.org/>. [13 March 2017]. 
European Financial and Accounting Journal, 2017, vol.12, no. 2, pp. 41-54.

Popovici, O. C., 2016. Determinants of FDI in the new EU Member States. Romanian Econ. Bus. Rev. 11, 173.

Wolff, G. B., 2007. Foreign Direct Investment in the Enlarged EU. Do Taxes Matter and to What Extent? Open Econ. Rev. 3, 327-346. DOI: 10.1007/s11079007-9041-9. 
